\title{
The Negative Influence of Labour Informality on Subjective Well-Being ${ }^{1}$
}

\author{
Benjamin (Benny) Temkin, FLACSO, Mexico
}

\begin{abstract}
This paper explores the relationship between informal employment and the subjective well-being of informal employees and self-employed workers in Mexico. The main hypothesis is that labor informality has a significantly negative impact on the level of self-reported life satisfaction and happiness of individuals. This effect is sustained even when controlling for potentially determinant socio-demographic factors, in particular income. The module of self-reported well-being (BIARE) that was part of the National Household Spending Survey (ENGASTO), conducted by the National Institute of Statistics and Geography (INEGI) during the first quarter of 2012 was used for this research. The module gathered, for the first time in Mexico, official statistics on life satisfaction and happiness. The results of the investigation show that informal employment is by itself a factor comparable to income in its influence on the perceived well-being of individuals.
\end{abstract}

\section{KEY WORDS}

Informal employment, income, subjective well-being, happiness, life satisfaction, life domains

\section{Introduction}

Few cultural and economic concepts have enjoyed such a persistent and extended hegemony as that which has directly equated the well-being of individuals and nations with economic progress, and particularly with personal and national income (and, therefore, with the level of consumption). For the past several years, psychologists and social scientists - even many economists, and more recently the makers of public policy - have increasingly questioned this direct and automatic association. Economic indices have ceased to be considered sufficient to determine the level of life satisfaction and/or happiness of citizens. This new perspective asserts that the well-being of individuals is influenced by a combination of objective and subjective components that may not coincide with each other in all cases ${ }^{2}$. In response to this developing consensus, an increasing number of

${ }^{1}$ I wish to thank Esther Martinez, Diana Penagos, Isaac Cisneros and Jorge Cruz for their research assistance and Rodrigo Negrete of INEGI for his kind advice.

2 For example, in Latin America, citizens in Guatemala and Venezuela show, on average, levels of subjective well-being well above what you would expect given the national economic indicators, while in Chile and 
governments and international institutions have engaged in collecting, analysing and comparing information on the self-perceived well-being of individuals.

Authors like Diener, Suh, Lucas and Smith (1998), De Neve and Cooper (1998), Yuste, Rubio and Aleixandre (2004), Alarcón (2006), Arraga and Sánchez (2010) and Rojas (2011) maintain that personal evaluations of life satisfaction require that individuals consider various dimensions associated with both the objective conditions that they confront in different aspects of their lives, as well as the frequency and intensity of positive and negative emotions they experience in their daily activities and social interactions. These various components are those that shape the cognitive and affective assessment they make of their lives, and with this, the level of satisfaction and/or happiness they experience.

The domains of life that have been considered central to the self-assessment of people about their satisfaction with life or their happiness include: health; economic situation; job or occupation; close family relationships; relationships with distant family, friends and neighbours; the availability and satisfying use of free time; and the conditions of the community or national environment (Rojas, 2011). The differential impact of these variables on subjective well-being has been studied by Rojas and Veenhoven (2013). The domains they consider are constructed on the basis of different sets of questions which are used to enquire about a number of crucial life dimensions: health, consumption, family, work, friendships, housing and so on. They detect a differentiated relationship between the diverse life domains of individuals and their subjective well-being.

In this paper, we investigate the impact that a specific area of life - their job or occupation has on the subjective well-being of individuals. Because people, during long spells of their lives, dedicate a good part of the day and their vital energy to labour activities, it is clearly important to understand the influence of the labour situation on their level of life satisfaction and happiness.

Various authors have shown not only that a positive association exists between job satisfaction and life satisfaction, but also that it is necessary to treat the labour environment as a critical dimension in the determination of subjective well-being of individuals (Tait, Padgett and Baldwin, 1989; Thorensen et al., 2003; Michalos and Orlando, 2006; Bowling, Eschleman and Wang, 2009). Along the same lines, the European Union conducted the First European Quality of Life Survey, which found that some working conditions - pressures of work and time - show negative associations with subjective well-being (Eurofound, 2007). That is to say, greater levels of stress in the workplace are linked to lower levels of life satisfaction.

As already mentioned, the subjective well-being of individuals has traditionally been associated with their economic status, which is generally measured by personal or family income. This would suggest that higher economic remuneration for work performed is directly translated into superior levels of personal satisfaction. However, authors such as Rojas (2011) have argued that the wage level or the resulting capacity to consume do not prove to be a perfect referent of subjective well-

Argentina it is just the opposite (Torres, 2010). This apparent paradox suggests that subjective well-being is multidimensional in nature, and its analysis requires the consideration of various areas that impact the selfperception of life satisfaction or happiness of individuals. Mexico constitutes a clear example of a disconnect between relatively low levels of national socio-economic indicators of human development and its very high indicators of subjective well-being (Temkin and Del Tronco, 2006). Undoubtedly, some of the differences between the levels of subjective well-being in different nations are due to cultural differences (Fleche, Smith and Sorsa, 2011). Since this research is comparing social groups within one country, culture is assumed to be homogenous for all subjects, and thus there is no need to include it as a control variable. 
being.

This paper focuses on a specific labour situation that involves an increasing number of participants in the workforce in numerous countries, particularly in those with lower levels of economic development. It addresses what is defined as labour informality, informal employment or atypical forms of employment.

Informal employment refers to a great variety of occupations in a wide range of workplaces These include street vendors and self-employed individuals owning micro-enterprises, as well as their salaried or unpaid employees.. Also included among the informally employed are people who work without official contracts or benefits, like social security and health insurance, in formally established companies or institutions. Domestic workers are also informal workers. To summarise, the concept of informal employment refers to the significant part of the global workforce that remains outside the world of full-time, stable, and protected jobs (International Labour Organisation, 2012).

The Organisation for Economic Cooperation and Development (OECD, 2009) estimates that approximately 60 per cent of the jobs in the world are informal, and by 2020 it expects that the proportion of informal employment will reach 66 per cent. In Latin America, the percentage rose from an average of 52.5 per cent between 1994 and 1999 to 57 per cent between 2000 and 2007, while in Southeast Asia it increased from 53 per cent between 1985 and 1989 to 70 per cent between 1995 and 1999 (Vega, 2009). In Mexico, the National Institute of Statistics and Geography (INEGI, 2013a), indicated in its 2013 report that the rate of informal employment had reached 60 per cent of the workforce.

Given this context of expansion of the phenomenon, and the importance labour informality has for public policy in many nations, the relative dearth of research on the subjectivity of informal employees and the informally self-employed is remarkable. The same is true concerning the impact of labour informality on the subjective well-being of individuals. In Latin America, for example, in spite of the fact that frequent surveys are conducted on the opinions, attitudes and values of Latin Americans - World Values Survey, LAPOP, Latinobarómetro - the relationship between the conditions of the workplace and subjective well-being has been studied rather sparingly through large $\mathrm{N}$ surveys. Some examples of this type of research are: Graham and Pettinato (2001), Fuentes and Rojas (2001), Moyano and Ramos (2007), Pagés and Madrigal (2008), Temkin (2009), Torres (2010) and

Rojas (2011). The research reported here, aims to assess the relationship between informality as a particular modality of the labour situation - and the subjective well-being of informal employees and self-employed in Mexico. This endeavour is important since the few studies on the subject that have been published report contradictory findings. Some have claimed that informal employment is positively associated with subjective well-being (Moyano, Castillo and Lizana, 2008; Pagés and Madrigal, 2008; Rojas 2013), while others have found the opposite (Temkin, 2009; Beytía, 2011).

The main hypothesis of this paper is that informal employment has a deleterious influence ${ }^{3}$ on the well-being of individuals, and that this negative impact holds true independently of the level of income they earn. This association between labour informality and low levels of self-reported wellbeing prevails even for many informally employed individuals who earn relatively high incomes. In the Mexican case, for example, one in every four informal employees work without contracts, health

3 The use of the terms influence, impact and effect of the independent variables on subjective well-being, derive from the results of the "marinal effects" analysis carried out for the empirical data on which this paper is based.

Global Labour Journal, 2016, 7(1), Page 71 
and social insurance or pensions, in the formal sector of the economy (formal enterprises, regional and federal governments and private institutions), some of them earning better than average incomes, at least temporarily. Also, some self-employed individuals owning economic units in the informal sector receive relatively high incomes. In other words, while labour informality and low income are strongly and positively correlated, the association is certainly not perfect.

The theoretical rationale for expecting low levels of subjective well-being among the overwhelming majority of informal workers, even among those earning better than average incomes, is that informally employed individuals are legally unprotected, their employment and income are unstable, and they live with high levels of insecurity regarding different aspects of their life, their health, their occupation, their encounters with authorities, and so on. All of these characteristics of informal employment have been shown to have negative impacts on the physiological and psychological health of people. In brief, informally employed individuals experience social, economic and psychological stress, insecurity and instability, and thus they manifest lower levels of well-being (Ferrie et al., 1998; Ferrie et al., 2001; Bardasi and Francesconi, 2004; Artazcoz et al., 2005; Benach et al, 2014; Kuykendall and Tay, 2015).

While recognising that these impacts can be partly attributed to the low levels of income earned by most informally employed individuals, this research will show that labour informality has, in and of itself, a negative effect on the subjective well-being experienced by individuals in most life domains, as well as on their level of general life satisfaction and happiness. More formally expressed, the hypothesis guiding this research endeavour is that informal employment has a statistically significant negative impact on the level of subjective well-being of individuals. This effect is sustained, even when controlling for other potentially determinant socio-demographic factors, in particular income. Furthermore, as will be shown below, the statistical analysis of the data indicates that the impact of informal employment on subjective well-being is comparable with that of income.

\section{Methodology}

The data generated by the Module of Self-reported Well-being (BIARE) that was applied together with the National Household Spending Survey (ENGASTO), conducted by INEGI during the first quarter of 2012, provides the empirical base for this research. Since 1984, the ENGASTO survey has collected information about expenditure in goods and services of individuals and families as well as about diverse occupational and social characteristics, living conditions and buying power of households. The BIARE gathered - for the first time in Mexico - official statistics on the subjective well-being of individuals, including the complete gamut of components of happiness and life satisfaction.

The design of the BIARE module followed various recommendations by the OECD and a select group of international experts. ${ }^{4}$ This collaborative work allowed INEGI to generate

4 Among them were Amartya Sen, Joseph Stiglitz, Daniel Kahanemann and Jean-Paul Fitoussi. The information gathered by the BIARE fulfilled the commitments made by Mexico to the Latin American Conference for the Measurement of Well-Being and the Progress of Societies in 2011 (http://mfps.inegi.org.mx/Default.aspx). The design of the module took into account elements of the European Social Survey (http://www.europeansocialsurvey.org/) regarding the insertion of individuals in their social milieu. 
representative statistics at the national level on subjective well-being in Mexico that are comparable with those of other countries which have begun to produce similar information. The underlying assumption of the unprecedented decision to produce official statistics on subjective life satisfaction is that the indicators that can be expressed monetarily are insufficient to understand the impact of those intangible goods that also determine subjective well-being. In this lies the vital importance of this kind of effort.

The BIARE was applied to a particularly large national representative sample of 10654 individuals. Of those, this study focuses on the 6343 respondents who participated in the workforce. ${ }^{5}$ That sub-sample was in turn divided into formally or informally employed individuals according to whether or not they had social security and health insurance as direct benefits associated with their employment. ${ }^{6}$ The informally employed are individuals who do not enjoy those benefits. Formal workers, on the other hand, are those who have social security as a compensation directly linked to their jobs. Thus, the main independent variable explored in this paper is the type of employment, formal or informal. For comparison purposes, the study also looked at high or low income as an alternative independent variable. It should be noted that in this paper, expenditure (consumption) is used as a proxy of income. This is partly because the ENGASTO Survey does not include a question on income, but also because, according to the World Bank (2008), in a developing country such as Mexico the living standards of families and individuals are easier to gauge using expenditure as a measure. ${ }^{7}$

The three dependent variables considered refer to the main ways in which the subjective wellbeing of individuals is conceptualised and measured in the relevant literature on the subject as well as by the BIARE itself. Subjective well-being is usually associated with (a) general life satisfaction, alluding to the way people reflectively evaluate their life as a whole; (b) happiness, referring to the hedonic

5 Actually, the number of respondents of the BIARE who identified themselves as part of the work force, was 7 194, but 851 of them had either lost data or had given contradictory information regarding their type of employment.

6 The internationally accepted conceptualisation of informal employment refers to any job that is carried out without legal or institutional protection, be it in an unregistered economic unit (informal sector) or in a formally established unit such as an enterprise, government or institution (OECD, 2012). Since in Mexico the main expression of legal and institutional protection for any type of employment is being registered for social security (Seguro Social), enjoying this benefit is consistently used as the operational variable for formal employment, and the lack of it as informal . To be precise, the informally employed were defined as those participants in the workforce who did not have health and social insurance directly through their workplace, as well as those who, though affiliated to the Seguro Social, their affiliation resulted from being a dependent of a person who does receive this benefit as a direct result of his or her employment. This definition is consistent with the International Laboor Organisation's operationalisation of the concept of informal employment (ILO, 2012).

7 This is how the World Bank deals with the option of using income or expenditure to measure living standards: "Income and expenditure data are both difficult to collect. In developed countries in which a large proportion of the population works in the formal sector and in which consumption patterns are very complex, the balance often tips in favor of measuring income rather than consumption. Even so, these surveys often have considerable problems dealing with self-employment, informal economic activities, and widespread reluctance to disclose information on income to survey enumerators. In developing countries, formal employment is less common, many households have multiple and continually changing sources of income, and home production is more widespread. In these contexts, it is generally far easier to measure consumption than income" (World Bank, 2008: 71). 
feelings about their life as reported by individuals at a specific point in time; and/or (c) satisfaction with life domains as a general construct of a number of crucial areas of personal life and understood as the net result of satisfaction or dissatisfaction in those domains (Rojas, 2011; OECD, 2012; INEGI, 2015).

\section{Findings and Discussion}

The descriptive data in Table 1, which shows the socio-demographic differences between formal and informal subjects in the sample, confirms the findings of previous research on these groups (Blunch, Canagarajah and Raju, 2001; Liimatainen, 2002; Temkin, 2009; Negrete, 2010; ILO, 2013). Females tend to be informally employed proportionally more than males. The same is true for the youngest and the oldest individuals in the population, as well as for those with lower levels of schooling. Finally, informal employment is associated with lower standards of living.

As a first step in the analysis of the data, a difference of means analysis was carried out, comparing the association between the independent variables, labour informality and income, and the three dependent variables of interest. As can be appreciated in Table 2 the results are significant and very similar for both income and type of employment. Both informality and low income have a negative and significant relation with subjective well-being.

The second step was to estimate three ordinal logistic regressions ${ }^{8}$ to calculate the statistical significance of the association (and its direction) of the independent and control variables with the three dependent variables of interest. The control variables for the regression models were sex, age, education and affective balance (see Table $\mathrm{A}$ in the Appendix). The last variable, affective balance, refers to a set of questions included in the BIARE that deal with the positive or negative emotional states of the respondents on the day before the BIARE questionnaire was answered or, in other words, to the net result of their most recent positive or negative life experiences (INEGI, 2013a; OECD, 2013). ${ }^{9}$ It is included as a control variable, because it has been claimed that very recent life events may impact the responses of individuals regarding their long-term satisfaction and happiness. The regressions results in Table 3 show that the control variables sex, age, affective balance (but not education), as well as the independent variables of income and informality, are significantly associated with the three dependent variables related to subjective well-being.

\footnotetext{
8 Ordinal logistic regressions were estimated because the dependent variables in this study were recoded from an original categorical variable with ten categories to one of four categories with values labelled: $1=$ Unsatisfied; 2 = Barely Satisfied; $3=$ Satisfied; $4=$ Totally Satisfied. The technique that best fits ordinal categorical variables is the Ordered Logistic Regression, used to find the predictors to these variables given their ordinal nature: the values are ranked but the distance between categories is unknown (Norusis, 2012).

9 Affective balance expresses the average mood that an individual experiences the day before being interviewed. To measure the affective balance of an individual four questions are asked about four different conditions: joy and tranquillity (positive conditions) along with anger and sadness (negative conditions). Each condition is given a grade from 0 to 10 . After that, negative conditions are subtracted from positive conditions and the result is divided by 20 , so it is expressed in a scale that goes from -1 to +1 . This indicator reflects a rank of emotional well-being that goes from the worst to the best situation possible on the immediately preceding day, and it is utilised as a control variable for the measurement of happiness and life satisfaction as a global evaluation (INEGI, 2015).
} 


\begin{tabular}{|c|c|c|c|}
\hline \multicolumn{4}{|c|}{ Gender } \\
\hline Gender & Formal Employment & Informal Employment & Total \\
\hline Female & $34.06 \%$ & $65.94 \%$ & $100 \%$ \\
\hline Male & $40.06 \%$ & $59.94 \%$ & $100 \%$ \\
\hline \multicolumn{4}{|c|}{ Age } \\
\hline Age & Formal Employment & Informal Employment & Total \\
\hline $18-24$ & $32.37 \%$ & $67.63 \%$ & $100 \%$ \\
\hline $25-35$ & $40.72 \%$ & $59.28 \%$ & $100 \%$ \\
\hline $36-45$ & $39.29 \%$ & $60.71 \%$ & $100 \%$ \\
\hline $46-55$ & $38.42 \%$ & $61.58 \%$ & $100 \%$ \\
\hline $56-65$ & $30.73 \%$ & $69.27 \%$ & $100 \%$ \\
\hline 66 or more & $22.86 \%$ & $77.14 \%$ & $100 \%$ \\
\hline \multicolumn{4}{|c|}{ Education } \\
\hline School Level & Formal Employment & Informal Employment & Total \\
\hline None & $9.28 \%$ & $90.72 \%$ & $100 \%$ \\
\hline $\begin{array}{c}\text { Complete elementary } \\
\text { school }\end{array}$ & $18.68 \%$ & $81.32 \%$ & $100 \%$ \\
\hline $\begin{array}{c}\text { Complete secondary } \\
\text { school }\end{array}$ & $34.51 \%$ & $65.49 \%$ & $100 \%$ \\
\hline Complete high school & $47.60 \%$ & $52.40 \%$ & $100 \%$ \\
\hline $\begin{array}{l}\text { Undergraduate or } \\
\text { graduate education }\end{array}$ & $61.62 \%$ & $38.38 \%$ & $100 \%$ \\
\hline \multicolumn{4}{|c|}{ Monthly Household Expenditure in Mexican Pesos (Proxy of Income) } \\
\hline \multicolumn{2}{|c|}{ Formal Employment } & \multicolumn{2}{|c|}{$\$ 17,903.10$} \\
\hline \multicolumn{2}{|c|}{ Informal Employment } & \multicolumn{2}{|c|}{$\$ 10,056.40$} \\
\hline \multicolumn{4}{|c|}{ Monthly Household Expenditure in Mexican Pesos } \\
\hline \multicolumn{2}{|c|}{ Mean Monthly Household Expenditure } & \multicolumn{2}{|c|}{$\$ 12,987.17$} \\
\hline \multicolumn{2}{|c|}{ Median Monthly Household Expenditure } & \multicolumn{2}{|c|}{$\$ 7,808.94$} \\
\hline \multicolumn{4}{|c|}{ Source: Own elaboration using data from BLARE-ENGASTO (INEGI) } \\
\hline
\end{tabular}




\section{Table 2. Mean differences for three dependent variables of interest}

\begin{tabular}{|c|c|c|c|c|c|c|c|c|c|c|c|c|}
\hline & \multicolumn{6}{|c|}{ Formal-Informal } & \multicolumn{6}{|c|}{ High and low income } \\
\hline $\begin{array}{c}\text { Dependent } \\
\text { variables }\end{array}$ & Formal & Informal & Difference & Min & Max & Sig. & $\begin{array}{l}\text { High } \\
\text { Income }\end{array}$ & $\begin{array}{l}\text { Low } \\
\text { Income }\end{array}$ & Difference & Min & Max & Sig. \\
\hline Happiness & 8.53 & 8.28 & -0.25 & 0 & 10 & 0.000 & 8.51 & 8.27 & -0.24 & 0 & 10 & 0.000 \\
\hline $\begin{array}{l}\text { Satisfaction with } \\
\text { life domains }\end{array}$ & 3.38 & 3.19 & -0.20 & 1 & 4 & 0.000 & 3.38 & 3.16 & -0.23 & 1 & 4 & 0.000 \\
\hline $\begin{array}{l}\text { Satisfaction with } \\
\text { life in general }\end{array}$ & 9.31 & 8.86 & -0.45 & 1 & 11 & 0.000 & 9.31 & 8.80 & -0.51 & 1 & 11 & 0.000 \\
\hline
\end{tabular}

Table 3. Models of ordinal logistic regression predicting being "Strongly Satisfied" or "Very Happy" (for dependent variables of interest)

\begin{tabular}{|c|c|c|c|}
\hline & M1 & M2 & M3 \\
\hline $\mathbf{Y}$ & Happiness & Life domains & Life in general \\
\hline Informal & $-0.136 * *$ & $-0.235^{* * *}$ & $-0.239 * * *$ \\
\hline Sex (Man) & 0.034 & -0.009 & 0.022 \\
\hline Income & -0.059 & $-0.321 * * *$ & $-0.283 * * *$ \\
\hline Age (Compared to “18-24”) & & & \\
\hline $25-35$ & $-0.171 * *$ & -0.032 & -0.047 \\
\hline $36-45$ & $-0.218^{* *}$ & $-0.138^{*}$ & $-0.155^{* *}$ \\
\hline $46-55$ & $-0.359 * * *$ & $-0.202^{* *}$ & $-0.215^{* *}$ \\
\hline $56-65$ & $-0.360 * * *$ & -0.094 & -0.095 \\
\hline 66 or more & $-0.474 * *$ & $-0.332 *$ & -0.217 \\
\hline Education (Compared to "None" & & & \\
\hline Complete Elementary School & 0.100 & -0.159 & -0.161 \\
\hline Complete Secondary School & 0.022 & -0.076 & -0.146 \\
\hline Complete High School & -0.098 & -0.033 & -0.150 \\
\hline Undergrad or Grad Education & -0.057 & -0.003 & -0.160 \\
\hline Affective Balance & $0.398 * * *$ & $0.399 * * *$ & $0.405^{* * *}$ \\
\hline Obs. & 6301 & 6301 & 6301 \\
\hline Pseudo R2 & 0.054 & 0.086 & 0.057 \\
\hline Prob> chi 2 & 0.000 & 0.000 & 0.000 \\
\hline \multicolumn{4}{|c|}{$p<0.1^{*}, p<0.05^{* *}, p<0.001^{* * *}$} \\
\hline
\end{tabular}


Finally, since the coefficients obtained in the regression model do not indicate the differential impact of the independent variables (income and type of employment) on the levels of subjective well-being, it was necessary to carry out three estimations of marginal effects (one for each of the three dependent variables). ${ }^{10}$ In each one of the regressions the marginal effects on the dependent variable were calculated for the change in the labour situation from formal to informal, as well as from high to low income ${ }^{11}$ respectively. Also, it is imperative to point out that in all instances when the impact of income was considered as the independent variable, informal employment was included as a control variable, and the other way around. These results are shown in Figure 1 and Tables 4 and 5.

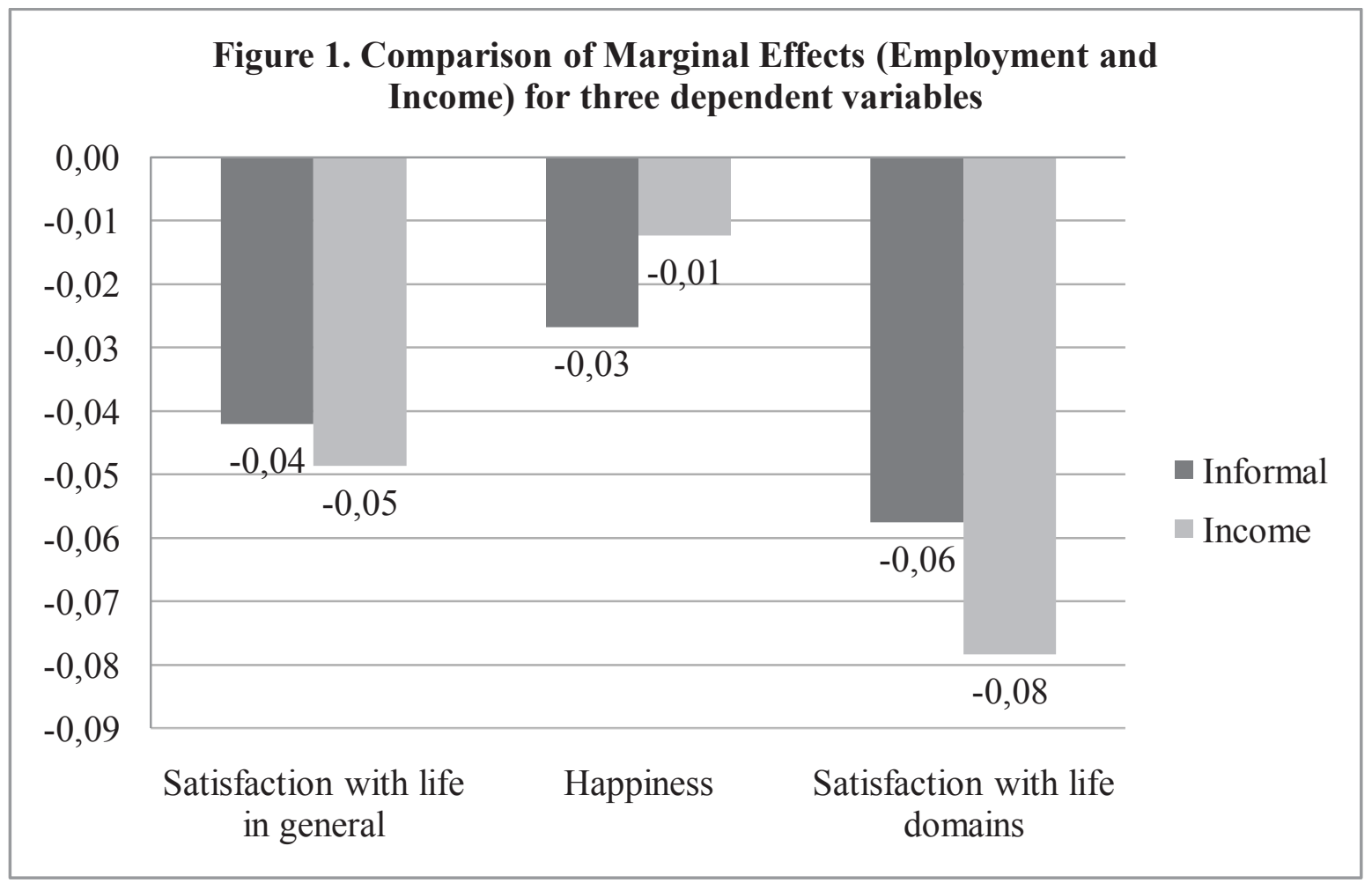

10 The SAGE Encyclopedia of Social Science Research Methods describes marginal effects as follows: "In regression analysis, data analysts are oftentimes interested in interpreting and measuring the effects of independent (or explanatory) variables on the dependent (or response) variable. One way to measure the effects of independent variables is to compute their marginal effects. The marginal effect of an independent variable measures the impact of change in an independent variable (e.g., $X_{i}$ ) on the expected change in the dependent variable (e.g., Y) in a regression model, especially when the change in the independent variable is infinitely small or merely marginal" (Wang, 2004: 609).

11 The cutting point between high and low income is the median of the natural logarithm of income equivalent to 8332.75 pesos. Income above that cutting point is high and below it is low. 


\begin{tabular}{|c|c|c|c|c|}
\hline \multirow[b]{2}{*}{ Happiness } & Mean & Sig. & Std. Err. & [95\% Conf. Interval] \\
\hline & \multicolumn{2}{|l|}{-0.01} & 0.010 & $-0.03307 \quad 0.00759$ \\
\hline Satisfaction with life domains & \multicolumn{2}{|c|}{$-0.08 *$} & 0.014 & $-0.10455-0.05076$ \\
\hline Satisfaction with life in general & \multicolumn{2}{|c|}{$-0.05 *$} & 0.009 & $-0.06544-0.03187$ \\
\hline \multicolumn{5}{|c|}{ Notes: $N=6,301 . * p<.05$} \\
\hline \multicolumn{5}{|c|}{ Source: Own elaboration using data from BLARE-ENGASTO (INEGI) } \\
\hline
\end{tabular}

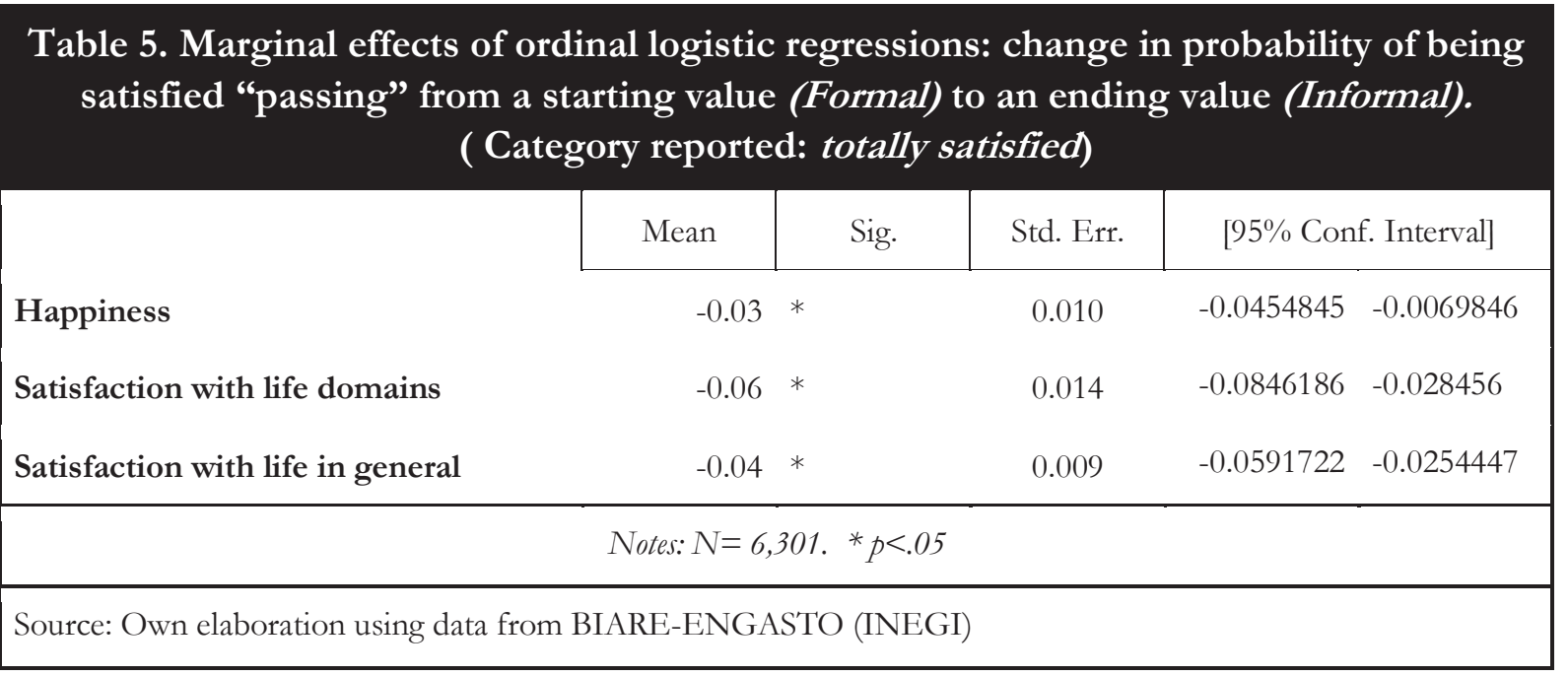

The statistical results presented above are consistent with the main hypothesis guiding this research effort. Informal employment impacts negatively on subjective well-being even when controlling for standards of living and other important socio-demographic and attitudinal variables. These results also confirm that the impact of labour informality is comparable with that of income for the three expressions of subjective well-being examined in this article.

Importantly, in addition to the information reported above, the data gathered by the BIARE, allows the extension of the research to evaluate the effects of labour informality on subjective wellbeing for specific life domains and aspects.

Particularly significant in this regard is the fact that the marginal effects analysis of the data makes it possible to evaluate the impact of informal employment (and comparatively that of income) on the satisfaction experienced by individuals specifically in relation to their work. The results in 
Tables 6 and 7, as well as Figures 2 and 3, clearly show that, compared with all other life domains, the strongest negative effects of informal employment on individual well-being are those linked with the person's job or occupation. Furthermore, the negative effect on job satisfaction is more robust for labour informality than for low income. Second, as can be appreciated, the negative influence of informal employment over satisfaction regarding diverse life domains is quite consistent. ${ }^{12}$. This finding suggests that labour informality has a generalised, negative and significant impact on the satisfaction with most life dimensions of individuals. (For specific analysis of life domains see Tables B, C1 - C2, and D1 - D2 in the Appendix).

However, in contrast to this clear pattern, a particularly interesting finding is that the impact of employment informality on the satisfaction with available time is not statistically significant. This finding is consonant with qualitative and quantitative studies by researchers who have found that an aspect frequently mentioned by informal workers as an advantage of their jobs and as a motivation not to seek formal employment, is the time flexibility that is allowed by informal employment (Hausmann, 2013; Pagés and Madrigal, 2008; Rojas, 2011; Temkin and Penagos, 2013). As has been pointed out by Zeytinoglu et al., (2005), such flexibility is particularly appreciated by working mothers with low income.

Table 6. Marginal effects ordinal logistic regressions. Change in probability of being satisfied "passing" from a starting value (high income) to an ending value (low income). ( Category reported: totally satisfied)

\begin{tabular}{|c|c|c|c|c|c|}
\hline \multirow[b]{2}{*}{ Work } & Mean & Sig. & Std. Err. & \multicolumn{2}{|c|}{ [95\% Conf. Interval] } \\
\hline & -0.06 & * & 0.010 & -0.08237 & -0.04361 \\
\hline Economic Situation & -0.04 & * & 0.004 & -0.04409 & -0.02981 \\
\hline Housing & -0.05 & $*$ & 0.007 & -0.06834 & -0.04233 \\
\hline Education & -0.03 & * & 0.005 & -0.03648 & -0.01684 \\
\hline Neighborhood & -0.03 & $*$ & 0.006 & -0.03737 & -0.01353 \\
\hline Family Life & -0.03 & * & 0.011 & -0.05167 & -0.00734 \\
\hline Heath & -0.02 & & 0.010 & -0.03646 & 0.00434 \\
\hline Affective Life & -0.06 & * & 0.010 & -0.07415 & -0.03643 \\
\hline Social Life & -0.06 & * & 0.009 & -0.07307 & -0.03840 \\
\hline Available Time & -0.03 & $*$ & 0.007 & -0.03935 & -0.01285 \\
\hline Personal Secutity & -0.04 & * & 0.008 & -0.05846 & -0.02699 \\
\hline \multicolumn{6}{|c|}{ Notes: $N=6,301 . * p<.05$} \\
\hline
\end{tabular}

12 Beyond what has been said in this paper about the links between the precariousness of informal employment and its impact on life satisfaction, it is beyond the scope of this article to link theoretically all the specific mechanisms through which labour informality generates negative effects on the satisfaction of individuals in each particular life dimension. 
Table 7. Marginal effects ordinal logistic regressions. Change in probability of being satisfied "passing" from a starting value (Formal) to an ending value (Informal).

( Category reported: totally satisfied)

\begin{tabular}{|c|c|c|c|c|c|}
\hline & Mean & Sig. & Std. Err. & \multicolumn{2}{|c|}{ [95\% Conf. Interval] } \\
\hline Work & -0.10 & * & 0.009 & -0.11923 & -0.08232 \\
\hline Economic Situation & -0.02 & * & 0.003 & -0.03135 & -0.01901 \\
\hline Housing & -0.04 & * & 0.007 & -0.04957 & -0.02321 \\
\hline Education & -0.02 & * & 0.005 & -0.03178 & -0.01229 \\
\hline Neighborhood & -0.01 & & 0.006 & -0.01925 & 0.00403 \\
\hline Family Life & -0.04 & * & 0.012 & -0.06525 & -0.01905 \\
\hline Health & -0.03 & * & 0.010 & -0.05547 & -0.01474 \\
\hline Affective Life & -0.04 & * & 0.010 & -0.06187 & -0.02093 \\
\hline Social Life & -0.01 & & 0.008 & -0.02967 & 0.00349 \\
\hline Available Time & 0.01 & & 0.007 & -0.00192 & 0.02394 \\
\hline Personal Secutity & -0.01 & & 0.008 & -0.02134 & 0.00948 \\
\hline \multicolumn{6}{|c|}{ Notes: $N=6,301 . * p<.05$} \\
\hline
\end{tabular}

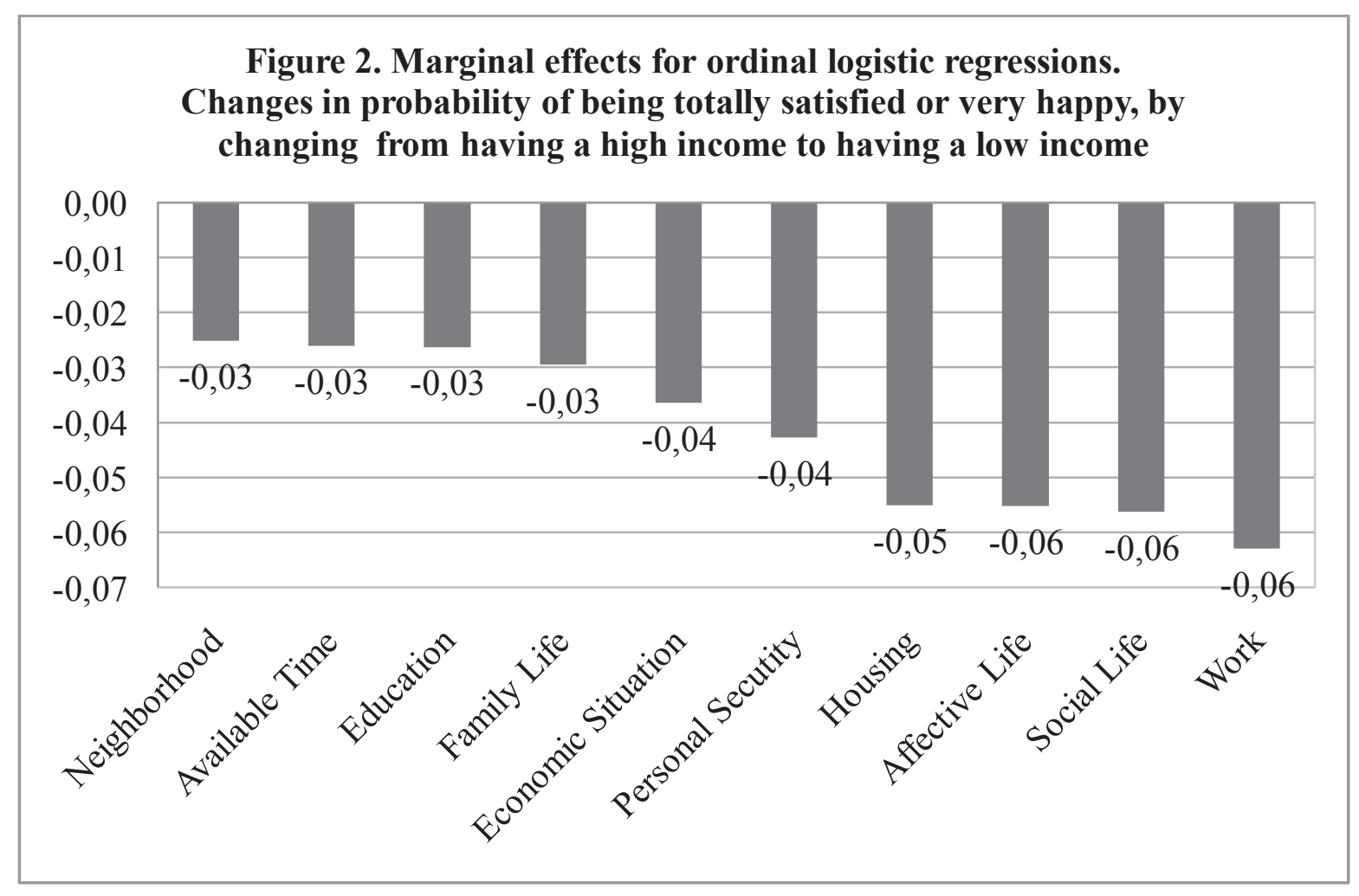




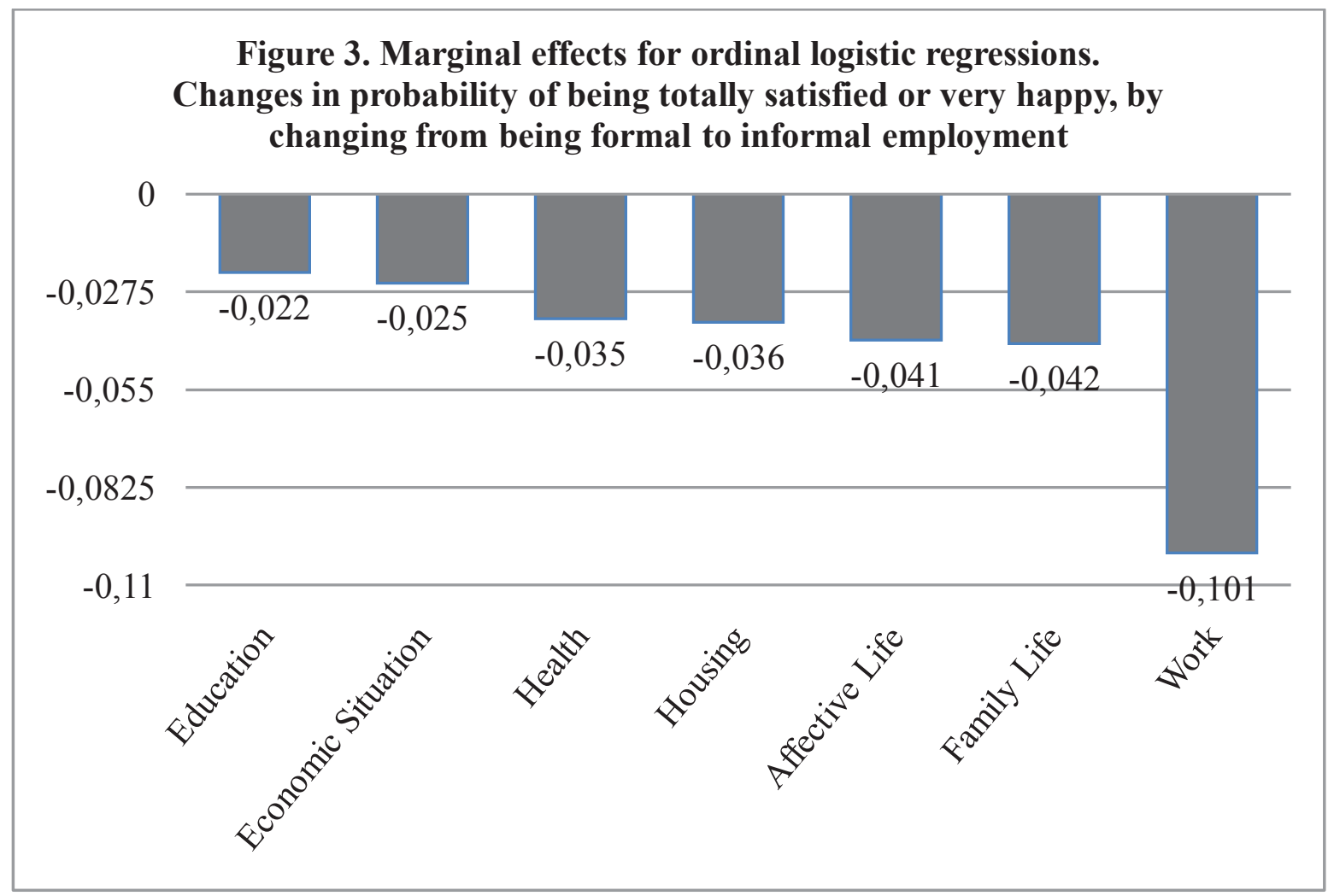

Finally, a rather surprising finding refers to the issue of the level of satisfaction with personal security. In spite of the illegal (though not criminal) nature of the activities of many informal workers, the data shows that they tend not to feel more insecure in their neighbourhoods of residence or work than formal participants in the workforce. This result seems to confirm the conclusions of Faúndez, (2009) and Temkin and Penagos (2013). According to them, many informal workers, particularly those in the informal sector of the economy, carry out their working activities within an institutional and cultural framework at the margins of legality, in which acts against the law are seen as part of their routine experience. Paradoxically this situation leads many of them to feel more secure in their homes and neighbourhoods than their formal counterparts. Not surprisingly, the findings reported above show no statistically significant difference between formal and informal workers in the level of satisfaction with the neighbourhoods where they live.

To summarise, the findings of this research effort empirically corroborate its central hypothesis regarding the negative impact of informal employment on the subjective well-being of individuals, and confirms the consistency of that impact across diverse life domains, including their jobs and occupations, while identifying life dimensions which are exceptional in this regard. The precariousness of informal employment, beyond the influence of low income, is clearly ascertained.

\section{Final Considerations: Labour Informality and Well-being}

The research presented in this paper should be placed in the context of recent discussions in two different fields, each apparently independent from the other. 
The first field deals with the ongoing debate about the causes of happiness and life satisfaction of people, and about the social, economic and cultural conditions that are conducive to greater or lesser subjective well-being of individuals. The second field refers to the social, economic and cultural impact of the growth of the "informal economy" and informal employment in the world, and especially in less-developed countries.

In recent years, there have been paradigmatic shifts with respect to the two issues, subjective well-being and labour informality. These changes have been reflected not only in theoretical discussions, but they have influenced the official statistical measurement and public policies concerning both problems.

On the one hand, the topic of well-being of individuals and nations, which for many years was monopolised by economics and particularly by the neo-classical version of that discipline, has been rescued for discussion and research by other disciplinary perspectives in the social and human sciences. A key outcome of this "paradigmatic revolution" has been the new emphasis on the multidimensional nature of the well-being of individuals and societies. Income and other economic variables are conceptualised now as a very important component, but not exclusively determinant of individual or social well-being.

Concerning economic informality, the movement has been in the direction of placing informal employment at the centre of the treatment of the topic. The theoretical and empirical interest with regard to informality has moved from the anthropological study of the "socio-economic marginality" of migrants in urban centres to the measurement of the size of the informal or "underground" economy, to the study of the economic, legal and technological characteristics of economic units in the "classic informal sector", and finally to the current interest in the informal participants in the labour force who may be working either in the "formal sector" or in the "informal sector" of the economy (Tilly and Denham, 2015).

These conceptual changes have begun to impact the measurement of both phenomena, individual and social well-being on the one hand, and informal employment on the other. With regard to the measurement of well-being, an international process of discussion and consultation is being conducted, with the participation of intellectuals and academics, officials from international institutions, political leaders, representatives of civil society, those responsible for the generation of national statistics and representatives of national governments. Its purpose is to generate common processes and criteria for the measurement of the satisfaction and happiness of individuals and societies (INEGI, 2013b). The consensus recognises the multidimensional nature of subjective wellbeing. The application of the BIARE module by INEGI, which constitutes the basis of the present research, is part of this new international agreement with regard to the measurement of well-being.

The conceptualisation and measurement of labour informality, on the other hand, has also been the subject of international discussion and has undergone changes over time. Its conceptual transformations have been reflected in the definition and operationalisation of economic and labour informality. Currently, the conception developed in the framework of the International Labour Organisation (2012) prevails. In the language of INEGI (2012: 1), the ILO conceptualisation deals with "an expanded concept of informality that already includes not only the employment of nonregistered economic units in which the business and the person are the same entity as part of the informal sector (street vendors, food preparation and other services offered in the public thoroughfare, cottage industries and handicrafts, etc.). Instead it also incorporates all employment that is not registered by the social security agency, whether it occurs in informal economic units, or 
in the formal sector itself.

Changes in the defining and statistical criteria concerning subjective well-being and informality that we have noted above are associated with new directions in public policy on both topics. Regarding well-being, the confirmation of its multidimensionality leads to the recognition that government actions and programmes must incorporate it as an essential public policy criterion. Failure to do so, and to focus exclusively on the generation of income "involves the risk of causing millions of people to end up less satisfied with their life, even when growth indicators are positive" (Foro Consultivo Científico y Tecnológico, 2012). On the other hand, the focus of the discussion on socio-economic informality, and its measurement in terms of informal employment (regardless of the sector in which it is found), can contribute to the design of better public economic and labour policies. To this end, the decision makers must understand that growing informality is a structural problem of the labour market in the global economy, and that public policy cannot "combat" informality only in the "classic informal sector" but also, and perhaps most effectively, by adopting economic and job creation policies geared to generate better-paid working conditions and with social benefits in the "formal sector".

The findings in this work constitute a contribution, based on empirical research, to these new perspectives in the study of labour informality and subjective well-being. Hopefully the results obtained may be useful in the design of public policies that enhance individual subjective well-being, by improving the working conditions of the participants in the workforce.

\section{REFERENCES}

Alarcón, R. (2006) Desarrollo de una Escala para medir la Felicidad. Revista Interamericana de Psicología/Interamerican Journal of Psychology, 40(1): 99-106.

Arraga, M. and M. Sánchez (2010) Bienestar Subjetivo en Adultos Mayores Venezolanos. Revista Interamericana de Psicología/Interamerican Journal of Psychology, 44(1): 12-18.

Artazcoz, L., J. Benach, C. Borrell and I. Cortés (2005) Social Inequalities in the Impact of Flexible Employment on Different Domains of Psychosocial Health. Epidemiology \& Community Health, 59: 761-7.

Bardasi, E. and M. Francesconi (2004) The Impact of Atypical Employment on Individual Wellbeing: Evidence from a Panel of British Workers. Social Science \& Medicine, 58(9): 1671-88.

Benach, J., A. Vives, M. Amable, C. Vanroelen, G. Tarafa and C. Muntaner (2014) Precarious Employment: Understanding an Emerging Social Determinant on Health. Annual Review of Public Health, 35: 229-53.

Beytía, P. (2011) El impacto del contexto social en los determinantes individuales de la felicidad: América Latina, Europa occidental y Estados Unidos en perspectiva comparada. Santiago de Chile: Pontificia Universidad Católica de Chile. Available online at https://www.academia.edu/3879964 (accessed 4 December 2015).

Blunch, N.H., S. Canagarajah and D. Raju (2001) The Informal Sector Revisited: A Synthesis Across Space and Time. Social Protection Discussion Paper Series (119). Washington, DC: World Bank. Available online at http://siteresources.worldbank.org/SOCIALPROTECTION/ Resources/SP-Discussion-papers/Labor-Market-DP/0119.pdf (accessed 10 December 2015). 
Bowling, N.A., K.J. Eschleman and Q. Wang (2010) A Meta-analytic Examination of the Relationship between Job Satisfaction and Subjective Well-being. Journal of Occupational and Organizational Psychology, 83(4): 915-34.

Deneve, K.M. and H. Cooper (1998) The Happy Personality: A Meta-analysis of 137 Personality Traits and Subjective Well-being. Psychological Bulletin, 124(2): 197-229.

Diener, E., E.M. Suh, R.E. Lucas and H.L. Smith (1998) Subjective Well-being. Three Decades of Progress. Psychological Bulletin, 125(2): 276-302.

European Foundation for Improvement of Living and Working Conditions (Eurofound) (2007) First European Quality of Life Survey: Overview. Luxembourg: Eurofound. Available online at http:/ / www.eurofound.europa.eu/areas/qualityoflife/eqls/2007/index.htm?utm_source=Eurof ound_News\&utm_medium=RSS\&utm_campaign=RSS, (accessed 15 May 2014).

Faúndez, J. (2009) Empowering Workers in the Informal Economy. Hague Journal on the Rule of Law, 1: 156-172.

Ferrie, J.E., M.J. Shipley, M.G. Marmot and P. Martikainen (2001) Job Insecurity in White-collar Workers: Toward an Explanation of Associations with Health. Journal of Occupational Health Psychology, 6(1): 26-42.

Ferrie, J.E., M.J. Shipley, M.G. Marmot, S. Stansfeld and G.D. Smith (1998) The Health Effects of Major Organizational Change and Job Insecurity. Social Science \& Medicine, 46: 243-54.

Fleche, S., C. Smith and P. Sorsa (2011) Exploring Determinants of Subjective Wellbeing in OECD Countries: Evidence from the World Value Survey. OECD Economics Department Working Papers No. 921. Paris: OECD. Available online at http://www.oecdilibrary.org/docserver $/$ download $/ 5 \mathrm{~kg} 0 \mathrm{k} 6 \mathrm{zlcm} 5 \mathrm{k} \cdot \mathrm{pdf}$ expires $=1449862259$ \&id $=\mathrm{id} \&$ accname $=\mathrm{gu}$ est\&checksum=AE9DB6728B6A52CFE8E9DC8AAE13F13F (accessed 11 December 2015).

Foro Consultivo Científico y Tecnológico, A.C (2012) Medición, Investigación e Incorporación a la Política Pública del Bienestar Subjetivo: América Latina. Available online at http:/ / www.foroconsultivo.org.mx/home/index.php/libros-publicados/medicion-delprogreso/981-medicion-investigacion-e-incorporacion-a-la-politica-publica-del-bienestarsubjetivo-america-latina (accessed 15 May 2014).

Fuentes, N. and M. Rojas (2001) Economic Theory and Subjective Well-Being: Mexico. Social Indicators Research, 53(3): 289-314.

Graham, C. and S. Pettinato (2001) Frustrated Achievers: Winners, Losers, and Subjective WellBeing in New Market Economies. Journal of Development Studies, 38(4): 100-140.

Hausmann, R. (2013) The Logic of the Informal Economy. Available online at http://www.projectsyndicate.org/commentary/the-logic-of-the-informal-economy-by-ricardo-hausmann (accessed 26 May 2014).

Instituto Nacional de Estadística y Geografía, Mexico (INEGI) (2012) Empleo informal en México. Press release 449/12. Aguascalientes: INEGI.

Instituto Nacional de Estadística y Geografía, Mexico (INEGI) (2013a) Indicadores oportunos de ocupación $y$ empleo. Available online at http://www.inegi.org.mx/inegi/contenidos/espanol/prensa/comunicados/ocupbol.pdf (accessed 15 May 2014).

Instituto Nacional de Estadística y Geografía, Mexico (INEGI) (2013b) Seminario bienestar subjetivo: su 
medición y uso en políticas públicas y toma de decisiones en México y Latinoamérica. Available online at http://www.inegi.org.mx/eventos/2013/bienestar_subjetivo/presentacion.aspx (accessed 15 May 2014).

Instituto Nacional de Estadística y Geografía, Mexico (INEGI) (2015) Balance Afectivo. Bienestar Subjetivo: BIARE Piloto. Available online at http://www.inegi.org.mx/inegi/contenidos/investigacion/experimentales/bienestar/presentaci on_p.aspx (accessed 10 December 2015).

International Labour Organisation (ILO) (2012) Measuring Informality: A Statistical Manual on the Informal Sector and Informal Employment. Available online at http://www.ilo.org/stat/Publications/WCMS_182300/lang--en/index.htm (accessed 15 May 2014).

International Labour Organisation (ILO) (2013) Women and Men in the Informal Economy: A Statistical Picture, Employment Sector. Geneva: International Labour Office.

Kuykendall, L. and L. Tay (2015) Employee Subjective Well-being and Physiological Functioning: An Integrative Model. Health Psychology Open, 2(1): 1-11.

Liimatainen, M.R. (2002) Training and Skills Acquisition in the Informal Sector: A Literature Review. ILO Working Papers. International Labour Organisation. Available online at http://www.ilo.org/wcmsp5/groups/public/---ed_emp/--ifp_skills/documents/publication/wcms_104010.pdf (accessed 10 December 2015).

Michalos, A. and J. Orlando (2006) Quality of Life of Some Under-represented Survey Respondents: Youth, Aboriginals and Unemployed. Social Indicators Research, 79(2): 191-213.

Moyano, E. and N. Ramos (2007) Bienestar subjetivo: midiendo satisfacción vital, felicidad y salud en población chilena de la Región Maule. Revista Universum. 22(2): 177-93. Available online at http://www.scielo.cl/scielo.php?script=sci arttext\&pid=S071823762007000200012\&lng=es\&nrm=iso (accessed: 15 May 2014).

Moyano, E., R. Castillo and J. Lizana (2008) Trabajo Informal: Motivos, bienestar subjetivo, salud, y felicidad en vendedores ambulantes. Psicologia em Estudo, 13(4): 693-701. Available online at http://www.scielo.br/pdf/pe/v13n4/v13n4a07 (accessed 4 December 2015).

Negrete, R. (2010) El empleo informal en México visto bajo el esquema conceptual OIT-Grupo de Delhi. Available online at http://wiego.org/sites/wiego.org/files/publications/files/Negrete _El.empleo.informal.Mexico.pdf (accessed 15 May 2014).

Norusis, M. (2012) IBM SPSS Statistics 19 Advanced Statistical Procedures Companion. New Jersey: Prentice Hall.

Organisation for Economic Cooperation and Development (OECD) (2009) Informality and Informal Employment. Available online at http://www.oecd.org/dac/povertyreduction/43280298.pdf (accessed November 2014).

Organisation for Economic Cooperation and Development (OECD) (2012) Guidelines on Measuring Subjective Well-being. Paris: OECD. Available online at http://www.inegi.org.mx/inegi/contenidos/investigacion/experimentales/bienestar/doc/biare basin15.pdf (accessed: November 2015).

Organization for Economic Cooperation and Development (OECD) (2013) Better Life Index. Available online at http://www.oecdbetterlifeindex.org/topics/life-satisfaction (accessed. 3 
September 2014).

Pagés, C. and L. Madrigal (2008) La calidad del trabajo: una cuestión de enfoque. In Calidad de vida: Más allá de los hechos, edited by E. Lora. Mexico City: Inter-American Development Bank and Fondo de Cultura Económica.

Rojas, M. (2011) El bienestar subjetivo: su contribución a la apreciación y la consecución del progreso y el bienestar humano. Realidad, datos y espacio, Revista internacional de estadística y geografía, 2(1): 64-77.

Rojas, M. (2013) The Subjective Well-being of People in Informal Employment: Empirical Evidence from Mexico. Evidence-based HRM: A Global Forum for Empirical Scholarship, 1(2): 169-86.

Rojas, M. and R. Veenhoven (2013) Contentment and Affect in the Estimation of Happiness. Social Indicators Research, 110(2): 415-31.

Tait, M., M. Padgett and T. Baldwin (1989) Job and Life Satisfaction: A Re-evaluation of the Strength of the Relationship and Gender Effects as a Function of the Date of the Study. Journal of Applied Psychology, 74(3): 502-7.

Temkin, B. (2009) Informal Self-employment in Developing Countries: Entrepreneurship or Survivalist Strategy? Some Implications for Public Policy. Analyses of Social Issues and Public Policy, $9(1): 135-56$.

Temkin, B. and J. Del Tronco (2006) Desarrollo Humano, Bienestar Subjetivo y Democracia: confirmaciones, sorpresas e interrogantes. Revista Mexicana de Sociología, 68(4): 731-60.

Temkin, B. and D. Penagos (2013) Actitudes y opiniones políticas de los informales en América Latina. América Latina Hoy. 63: 141-76.

Thorensen, C., S. Kaplan, A. Barsky, C. Warren and K. De Chermont (2003) The Affective Underpinnings of Job Perceptions and Attitudes: A Meta-analytic Review and Integration. Psychological Bulletin, 129(6): 914-45.

Tilly, C. and D. Denham (2015) Covering Divergences in Formal and Informal Work: Longitudinal Evidence from Mexico. Global Labour Journal, 6(1): 41-61.

Torres, G. (2010) Bienestar Subjetivo en América Latina. Available online at http://prodavinci.com/2010/01/29/economia-y-negocios/bienestar-subjetivo-en-americalatina (accessed 15 May 2014).

Vega, A. (2009) Empleo informal en el mundo alcanzará el 66\% en 2020. Al Día News. Available online at http://www.pontealdia.com/empleos/empleo-informal-en-el-mundo-alcanzara-el-66en-2020-2.html (accessed: 20 September 2015).

Wang, C. (2004) Marginal Effects. In The SAGE Encyclopedia of Social Science Research Methods, edited by M.S. Lewis-Beck, A. Bryman and T.F. Liao. Thousand Oaks, CA: Sage.

World Bank (2008) Analyzing Health Equity using Household Data: A Guide to Techniques and their Implementation. Washington, DC: World Bank. Available online at http:/ / siteresources.worldbank.org/INTPAH/Resources/Publications/459843-

1195594469249/HealthEquityFINAL.pdf (accessed 26 November 2014).

World Bank (2009) Doing Business 2010. Washington, DC: The World Bank, IFC and Palgrave MacMillan.

Yuste, N., R. Rubio and M. Aleixandre (2004) Introducción a la psicogerontología. Madrid: Pirámide. 
Zeytinoglu, I.U., B. Seaton, W. Lillevik and J. Moruz. (2005) Working in the Margins: Women's Experiences of Stress and Occupational Health Problems in Part-time and Casual Jobs. Women \& Health, 41(1): 87-108.

\section{BIOGRAPHICAL NOTE}

Benjamin (Benny) Temkin is a Professor at the Facultad Latinoamericana de Ciencias Sociales (Flacso - Mexico). He has taught at Columbia University, Tel-Aviv University, and the Hebrew University in Jerusalem. He has written extensively on informal employment and the informal sector. [Email: temkin@,flacso.edu.mx] 


\section{APPENDIX}

\begin{tabular}{|c|c|c|}
\hline \multicolumn{3}{|c|}{$\begin{array}{c}\text { Table A. Variables Description } \\
\text { Independent Variables }\end{array}$} \\
\hline Variable & Description & Categories \\
\hline $\begin{array}{l}\text { Type of } \\
\text { employment }\end{array}$ & $\begin{array}{l}\text { Dummy that distinguishes between having social insurance as an } \\
\text { employment benefit (Formal Employment), and being insured by any } \\
\text { other reason, or not being insured at all (Informal Employment). }\end{array}$ & $\begin{array}{l}0=\text { Formal Employment } \\
1=\text { Informal Employment }\end{array}$ \\
\hline Sex (Man) & Dummy variable for sex. & $\begin{array}{l}1=\text { Man } \\
0=\text { Woman }\end{array}$ \\
\hline Age & Age in categories. & $\begin{array}{l}1=18-24 \text { years } \\
2=25-35 \text { years } \\
3=36-45 \text { years } \\
4=46-55 \text { years } \\
5=56-65 \text { years } \\
6=66 \text { or more years }\end{array}$ \\
\hline Education & Ordinal variable that expresses the last school level. & $\begin{array}{l}1=\text { None } \\
2=\text { Complete Elementary } \\
\text { School } \\
3=\text { Complete Secondary } \\
\text { School } \\
4=\text { Complete High School } \\
5=\text { Undergraduate or } \\
\text { Graduate education }\end{array}$ \\
\hline Income & Dummy variable recoded from Household Expenditure. & $\begin{array}{l}0=\text { High Income }- \text { Household } \\
\text { Expenditure above the median } \\
\text { value. } \\
1=\text { Low Income - Household } \\
\text { Expenditure below the median } \\
\text { value. }\end{array}$ \\
\hline $\begin{array}{l}\text { Affective } \\
\text { Balance }\end{array}$ & $\begin{array}{l}\text { Average mood than an individual expressed regarding the day before } \\
\text { being interviewed. This variable was recoded from values from }-1 \text { to } \\
+1\end{array}$ & $\begin{array}{l}\text { Continuous variable - Range } \\
\text { from } 0 \text { to } 10 .\end{array}$ \\
\hline
\end{tabular}




\begin{tabular}{|c|c|c|c|c|c|}
\hline \multicolumn{6}{|c|}{$\begin{array}{c}\text { Table B. Descriptive Statistics } \\
\text { Dependent Variables of Interest }\end{array}$} \\
\hline Variable & Observations & Mean & $\begin{array}{l}\text { Standard } \\
\text { Deviation }\end{array}$ & Min. & Max. \\
\hline Happiness & 7194 & 8.38 & 1.74 & 0 & 10 \\
\hline $\begin{array}{c}\text { Satisfaction with life } \\
\text { domains }\end{array}$ & 7194 & 3.26 & 0.82 & 1 & 4 \\
\hline $\begin{array}{c}\text { Satisfaction with life in } \\
\text { general }\end{array}$ & 7194 & 9.04 & 1.90 & 1 & 11 \\
\hline \multicolumn{6}{|c|}{ Life Domains } \\
\hline Variable & Observations & Mean & $\begin{array}{l}\text { Standard } \\
\text { Deviation }\end{array}$ & Min. & Max. \\
\hline Work & 7194 & 8.25 & 3.14 & 0 & 11 \\
\hline Economic Situation & 7194 & 7.56 & 2.28 & 1 & 11 \\
\hline Housing & 7194 & 8.13 & 2.51 & 1 & 11 \\
\hline Education & 7194 & 8.03 & 2.47 & 1 & 11 \\
\hline Neighborhood & 7194 & 8.19 & 2.32 & 1 & 11 \\
\hline Family Life & 7194 & 9.52 & 1.77 & 1 & 11 \\
\hline Health & 7194 & 9.31 & 1.80 & 1 & 11 \\
\hline Affective Life & 7194 & 9.24 & 1.94 & 1 & 11 \\
\hline Social Life & 7194 & 8.80 & 2.17 & 1 & 11 \\
\hline Available Time & 7194 & 7.68 & 2.72 & 1 & 11 \\
\hline Personal Security & 7194 & 8.58 & 2.29 & 1 & 11 \\
\hline \multicolumn{6}{|c|}{ Source: Own elaboration using data from BLARE-ENGASTO (INEGI) } \\
\hline
\end{tabular}




\begin{tabular}{|c|c|c|c|c|c|c|}
\hline \multicolumn{7}{|c|}{ Formal-Informal } \\
\hline Dependent variables & Formal & Informal & Difference & Min. & Max. & Sig. \\
\hline Work & 9.06 & 7.87 & -1.19 & 0 & 11 & 0.000 \\
\hline Economic Situation & 8.08 & 7.25 & -0.83 & 1 & 11 & 0.000 \\
\hline Housing & 8.53 & 7.84 & -0.68 & 1 & 11 & 0.000 \\
\hline Education & 8.67 & 7.65 & -1.02 & 1 & 11 & 0.000 \\
\hline Neighborhood & 8.32 & 8.05 & -0.26 & 1 & 11 & 0.000 \\
\hline Family Life & 9.69 & 9.40 & -0.29 & 1 & 11 & 0.000 \\
\hline Health & 9.55 & 9.22 & -0.33 & 1 & 11 & 0.000 \\
\hline Affective Life & 9.48 & 9.07 & -0.42 & 1 & 11 & 0.000 \\
\hline Social Life & 9.00 & 8.66 & -0.34 & 1 & 11 & 0.000 \\
\hline Available Time & 7.70 & 7.62 & -0.08 & 1 & 11 & 0.252 \\
\hline Personal Security & 8.74 & 8.48 & -0.26 & 1 & 11 & 0.000 \\
\hline & a & $f$ & GASTO & & & \\
\hline
\end{tabular}




\begin{tabular}{|c|c|c|c|c|c|c|}
\hline \multicolumn{7}{|c|}{ High and low income } \\
\hline Dependent variables & High Income & Low Income & Difference & Min. & Max. & Sig. \\
\hline Work & 8.75 & 7.80 & -0.95 & 0 & 11 & 0.000 \\
\hline Economic Situation & 8.12 & 7.07 & -1.05 & 1 & 11 & 0.000 \\
\hline Housing & 8.62 & 7.69 & -0.93 & 1 & 11 & 0.000 \\
\hline Education & 8.68 & 7.46 & -1.21 & 1 & 11 & 0.000 \\
\hline Neighborhood & 8.43 & 7.97 & -0.46 & 1 & 11 & 0.000 \\
\hline Family Life & 9.68 & 9.38 & -0.30 & 1 & 11 & 0.000 \\
\hline Health & 9.45 & 9.19 & -0.26 & 1 & 11 & 0.000 \\
\hline Affective Life & 9.51 & 9.00 & -0.51 & 1 & 11 & 0.000 \\
\hline Social Life & 9.08 & 8.56 & -0.52 & 1 & 11 & 0.000 \\
\hline Available Time & 7.89 & 7.49 & -0.40 & 1 & 11 & 0.000 \\
\hline Personal Security & 8.83 & 8.36 & -0.47 & 1 & 11 & 0.000 \\
\hline \multicolumn{7}{|c|}{ Source: Own elaboration using data from BLARE-ENGASTO (INEGI) } \\
\hline
\end{tabular}




\section{Table D1. Models of ordinal logistic regression predicting being "Strongly Satisfied".}

(For Life Domains)

\begin{tabular}{|c|c|c|c|c|c|c|}
\hline & M1 & M2 & M3 & M4 & M5 & M6 \\
\hline $\mathbf{Y}$ & Work & Economic situation & Housing & Education & Neighborhood & $\begin{array}{l}\text { Family } \\
\text { Life }\end{array}$ \\
\hline Informal & $-0.546^{* * *}$ & $-0.404 * * *$ & $-0.272 * * *$ & $-0.216^{* * *}$ & -0.061 & $-0.188^{* * *}$ \\
\hline Man & -0.024 & $-0.081 *$ & $-0.145^{* * *}$ & $-0.141 * *$ & $-0.174 * * *$ & 0.005 \\
\hline Income & $-0.344 * * *$ & $-0.599 * * *$ & $-0.419 * * *$ & $-0.263^{* * *}$ & $-0.207 * *$ & $-0.132^{* *}$ \\
\hline $\begin{array}{l}\text { Age (Compared to " } 18 \text { - } \\
24 ")\end{array}$ & & & & & & \\
\hline $25-35$ & $0.122 *$ & -0.095 & $-0.161 * *$ & $-0.166 * *$ & 0.005 & -0.014 \\
\hline $36-45$ & $0.276^{* * *}$ & -0.046 & $0.127^{*}$ & $-0.137 *$ & $0.139 *$ & -0.021 \\
\hline $46-55$ & $0.256 * *$ & -0.040 & $0.309 * * *$ & -0.121 & $0.226^{* *}$ & $-0.149 *$ \\
\hline $56-65$ & $0.187^{*}$ & -0.082 & $0.466 * * *$ & -0.048 & $0.399 * * *$ & -0.114 \\
\hline 66 or more & 0.173 & 0.146 & $0.443^{* *}$ & 0.064 & $0.411 * *$ & -0.250 \\
\hline $\begin{array}{l}\text { Education (Compared to } \\
\text { "None") }\end{array}$ & & & & & & \\
\hline Complete Elementary & & & & & & \\
\hline School & 0.204 & $0.264 * *$ & 0.041 & $1.232^{* * *}$ & $-0.320 * *$ & -0.000 \\
\hline Complete Secondary & & & & & & \\
\hline School & $0.246^{*}$ & $0.392 * *$ & 0.151 & $1.728^{* * *}$ & $-0.399 * *$ & 0.060 \\
\hline Complete High School & $0.261 *$ & $0.555^{* * *}$ & $0.302^{* *}$ & $2.211 * * *$ & $-0.312 * *$ & -0.079 \\
\hline Undergrad or Grad & & & & & & \\
\hline Education & 0.222 & $0.635^{* * *}$ & $0.399 * *$ & $3.053^{* * *}$ & -0.095 & 0.102 \\
\hline Affective Balance & $0.201 * * *$ & $0.251 * * *$ & $0.217 * * *$ & $0.205^{* * *}$ & $0.187 * * *$ & $0.292 * * *$ \\
\hline Obs. & 6301 & 6301 & 6301 & 6301 & 6301 & 6301 \\
\hline Pseudo R2 & 0.025 & 0.039 & 0.028 & 0.063 & 0.016 & 0.034 \\
\hline Prob> chi2 & 0.000 & 0.000 & 0.000 & 0.000 & 0.000 & 0.000 \\
\hline \multicolumn{7}{|c|}{$p<0.1^{*}, p<0.05^{* *}, p<0.001^{* * *}$} \\
\hline
\end{tabular}




\section{Table D2. Models of ordinal logistic regression predicting being "Strongly Satisfied".}

(For Life Domains)

\begin{tabular}{|c|c|c|c|c|c|}
\hline & M7 & M8 & M9 & M10 & M11 \\
\hline $\mathbf{Y}$ & Health & Affective Life & Social Life & Available Time & Personal security \\
\hline Informal & $-0.170^{* *}$ & $-0.201 * * *$ & -0.078 & $0.081 *$ & -0.036 \\
\hline Man & $0.137 * *$ & 0.060 & 0.043 & $0.084^{*}$ & -0.007 \\
\hline Income & -0.076 & $-0.271 * * *$ & $-0.327 * * *$ & $-0.192 * * *$ & $-0.263 * * *$ \\
\hline $\begin{array}{l}\text { Age (Compared to "18 - } \\
24 ")\end{array}$ & & & & & \\
\hline $25-35$ & $-0.334 * * *$ & -0.004 & $-0.146^{* *}$ & $-0.296 * * *$ & -0.017 \\
\hline $36-45$ & $-0.559 * * *$ & -0.037 & $-0.231 * *$ & $-0.197 * * *$ & 0.021 \\
\hline $46-55$ & $-0.883^{* * *}$ & -0.094 & $-0.290 * * *$ & -0.052 & 0.009 \\
\hline $56-65$ & $-1.261 * * *$ & -0.133 & $-0.291 * *$ & 0.107 & -0.063 \\
\hline 66 or more & $-1.427 * * *$ & -0.194 & -0.219 & $0.552^{* * *}$ & 0.008 \\
\hline $\begin{array}{l}\text { Education (Compared to } \\
\text { "None") }\end{array}$ & & & & & \\
\hline Complete Elementary & & & & & \\
\hline School & -0.025 & 0.079 & -0.042 & -0.034 & $0.223^{*}$ \\
\hline Complete Secondary & & & & & \\
\hline School & -0.001 & 0.150 & -0.101 & -0.008 & $0.267^{* *}$ \\
\hline Complete High School & -0.064 & 0.202 & 0.035 & -0.026 & $0.244^{*}$ \\
\hline Undergrad or Grad & & & & & \\
\hline Education & 0.017 & $0.386^{* *}$ & 0.123 & 0.008 & 0.208 \\
\hline Affective Balance & $0.255^{* * *}$ & $0.298^{* * *}$ & $0.255^{* * *}$ & $0.195^{* * *}$ & $0.245^{* * *}$ \\
\hline Obs. & 6301 & 6301 & 6301 & 6301 & 6301 \\
\hline Pseudo R2 & 0.036 & 0.0381 & 0.0271 & 0.014 & 0.021 \\
\hline Prob> chi2 & 0.000 & 0.000 & 0.000 & 0.000 & 0.000 \\
\hline \multicolumn{6}{|c|}{$p<0.1^{*}, p<0.05^{* *}, p<0.001^{* * *}$} \\
\hline
\end{tabular}

